\title{
THE HISTORICAL AND PHILOSOPHICAL ASPECTS OF PUNISHMENT FOR THE CRIME
}

\author{
Ismoilov Ikhtiyorjon Azamjonovich \\ Independent Researcher of the Military-Technical Institute of the National Guard of the Republic of \\ Uzbekistan
}

Article DOI: https://doi.org/10.36713/epra4081

\begin{abstract}
The article analyzes the historical and philosophical aspects of sentencing criminal offenses using scientific literature and online sources.
\end{abstract}

KEY WORDS: crime, law, legal culture, law, task, concept, citizen.

\section{INTRODUCTION}

The system of criminal and criminal-legal legislation effectively protects the rights, freedoms and legitimate interests of citizens, the existence of legal barriers that prevent legality in criminal and judicial proceedings: prevention and prevention of crimes, as well as high legal culture and respect for citizens. inadequate legal mechanisms for absorption; inadequate sanction and ineffectiveness of sanctions for certain types of crimes, the nature and extent of socially dangerous acts, including alternative types of punishment, incentive norms and measures of social influence; unsatisfactory quality of operativelyinvestigative actions and use of the received information in violation of procedural legislation requirements; insufficient implementation of criminal law institutions recognized in international practice, including the lack of criminal liability of legal entities; The introduction of modern information and communication technologies in forensic investigations is very low and results of analysis of forensic practices as well as the results of direct communication with the people indicate that there are a number of systemic problems and shortcomings in this area.

\section{METHODS}

Creation of an effective system of criminal and criminal procedure legislation is one of the priority tasks of the state in ensuring law and order, protection of human rights and freedoms, public and state interests, peace and security, taking into account modern international standards and best international experience. and, in accordance with the Action Plan for the five priority areas of development of the Republic of Uzbekistan for the period of 2017-2021, it is necessary to identify the criminal and criminal procedure legislation. In order to develop and implement fundamentally new priorities of integration, the Presidential Decree №-3723 of May 14, 2018 “On Measures for the Radical Improvement of the Criminal and Criminal Procedure Legislation" was adopted and this resolution was adopted. - The concept of improvement of procedural legislation was approved.

\section{RESULTS AND DISCUSSIONS}

The Concept notes the inadequacy and ineffectiveness of certain social crimes, including alternative types of punishment, incentive norms, and public sanctions, as well as problems and drawbacks related to the imperfections of certain provisions in criminal and criminal procedure law. different interpretations or corruption cases, or the extent and nature of social danger th acts that are incompatible with the principles of established norms of the responsibility for removal; creation of effective legal mechanisms for the prevention and suppression of 


\section{EPRA International Journal of Research and Development (IJRD) \\ Volume: 5 | Issue: 2 | February 2020 \\ - Peer Reviewed Journal}

crimes, instilling high legal culture of citizens, their upbringing in compliance with the Constitution and laws; improvement of the criminal responsibility system and the revision of the classification system and criteria by introducing alternative indicators that determine the level and nature of criminal danger; ensuring a reliable guarantee of liability for the perpetrators of crimes; revision of punishment systems and mechanisms of their appointment, exclusion of outdated types and types of punishments; education of persons found guilty of committing a crime as well as the introduction of penalties and other legal measures aimed at preventing possible crimes; expanding incentives, including those that mitigate punishment or establish criminal liability or release; Improvement of norms that exclude criminality of acts; development of the institution for the use of compulsory medical measures; the need for greater human rights of criminal law, especially for the first time, which does not pose a significant social danger or less serious, as well as for socially vulnerable segments of the population - minors, the elderly, persons with disabilities, pregnant women and lonely children. As a result, it was emphasized that full implementation of the principle of "rule of law punishment is inevitable" is a requirement of time and life today.

The principle that is most important in understanding human rights is the idea of natural equality in the Greek and the Greek (Protagor, Antifont, Lycophron), and in the political and legal doctrines of Chinese thinkers (Mao-Tsi, Confucius) (VI-IV centuries BC). Former Roman statesman, speaker, and lawyer Mark Tulci Cicero also saved several people by executing a speech in court. In particular, Cicero said: "A judge should not rush to the death penalty against the perpetrator. After all, the judge cannot justify the justice of the judge and the court if the death of the person is not justified [2].

The well-known French writer W.Hugo described the importance of punishment in the fight against crime in his time, saying that "any punishment is cruel, and its characteristic is that it changes a person, but also changes his mind and his mind, and gradually. It will turn into a savage beast"[3].

In Islam, every human being has the right to enjoy human rights because it is a divine blessing. According to Islamic teachings, Allah created man as a human. Since life is given to man by Allah, no one can deprive him of the right to life.

The political and legal views of Abu Raykhan Beruni, one of the comedian scholars of the Shark Renaissance, have also focused on crime and punishment. According to the scholar, the worst manifestation of immorality in society is violence and theft. As for the punishment for such crimes and the reeducation of those who committed them, Beruni says: Theft is punishable by the amount of the stolen property. Sometimes it is punished with a severe and moderate punishment as an example to the people, sometimes interfering with the indoctrination and indemnification of the people, sometimes spreading and publicizing "[4, p.14].

Amir Temur's "Laws" also honors human rights and reveals the legal aspects of their protection. For example, it is written, "Anyone who has escaped from my office should be forgiven, even if he has committed a sin. Amir Temur insisted that the governor stand on the side of justice in protecting citizens' rights. When he heard from the governors that he had been oppressing the people, he acted with fairness to them. "If the drugs and the rulers are to oppress and ruin the people, then they must be punished for what they have done" [5, p.90].

In the book of Zadig or Destiny by the French writer and philosopher: "The greatest truth is that people must first find their way into the heart of the world, without resorting to sensual efforts to change the appearance of the world in exchange for bloodshed, in order to understand the meaning of life" [15] is injected.

\section{CONCLUSION}

The doctrines of crime and punishment are at the heart of all issues, such as the universal human dignity - the protection of human rights. Ancient wise men and statesmen paid special attention to this problem in their views and actions, informing the general public of them is an important social task. In particular, studying the rich ideas embodied in our political and legal heritage, the doctrines of thinkers about building a just and educated society, and their indepth considerations of crime and punishment will undoubtedly contribute to the theoretical enrichment of justice.

\section{REFERENCES}

1. Annex 1 to the Resolution of the President of the Republic of Uzbekistan dated May 14, 2018 №PP3723 CSMMB, dated 15.05.2018, No. $07 / 18 / 3723 / 1225$.

2. 20 wise quotes by Mark Tullius Cicero- 27.05.2014

3. "The Last Day of the Sentenced to Death" by V.Hugo. 1829 of publication 2007. Article 55.

4. Sharipov A.The great thinker Abu Reyhan Beruni Tashkent: Fan, 1972. -p.14.

5. "Temur's laws".-Tashkent: Science and Technology, 2014. - p.90.

6. «Zadig or destiny».-Moscow, 1985.-p.15. 